\title{
Glycosyltransferases in Human Blood
}

\author{
II. STUDY OF SERUM GALACTOSYLTRANSFERASE AND \\ $N$-ACETYLGALACTOSAMINYLTRANSFERASE IN \\ PATIENTS WITH LIVER DISEASES
}

\author{
Y. S. Kim, J. Perdomo, J. S. Whitehead, and K. J. Curtis \\ From the Gastrointestinal Research Laboratory, Veterans Administration \\ Hospital, San Francisco, California 94121, and Department of Medicine, \\ University of California School of Medicine, San Francisco, California 94122
}

\begin{abstract}
A B S T R A C T Serum galactosyltransferase activity was found to be elevated in patients with alcoholic and other liver disorders but remained at a normal level in patients with a variety of nonhepatic diseases. The properties of the galactosyltransferase in patients with liver disease were compared with those of the enzyme in the serum of normal subjects. The possible presence of inhibitors or activators in the serum was examined. Results indicated that in patients with liver disease, the rise in the serum galactosyltransferase was due to an increase in the level of the enzyme present in normal serum and not due to the appearance of a new enzyme. In the cases examined, the level of the enzyme increased with the deterioration of liver function and declined in a patient recovering from acute alcoholic hepatitis. Another glycosyltransferase, an $N$-acetylgalactosaminyltransferase, was not elevated in the serum of liver disease patients and, unlike the galactosyltransferase, was not detected in normal liver. The results suggest that the serum galactosyltransferase originates from the liver and that an abnormal rise in the level of this enzyme in serum is due to hepatocellular damage.
\end{abstract}

\section{INTRODUCTION}

It is now apparent that in addition to mucins and human blood group substances, immunoglobulins, most serum proteins, and many hormones and enzymes are glycoproteins (1-10), i.e. proteins with varying amount of covalently linked carbohydrate. Such enzymes have been shown to occur in many tissues that synthesize glycoproteins, e.g. liver $(11,12)$, gastrointestinal mucosa (13-

Received for publication 18 January 1972 and in revised form 6 March 1972.
16), submaxillary gland $(17,18)$, thyroid gland (19), and in other tissues and body fluids (20-22). In general, these enzymes are membrane bound (11-19). Just as defects in glycolipid metabolism have been shown to result in lipid-storage diseases and mucopolysaccharidoses (20), alterations in glycoprotein metabolism or structure have been implicated in a variety of disorders such as cystic fibrosis, gastric ulcer, gastrointestinal tumors, leukemia, and the microangiopathy of diabetes mellitus (23-29). However, the specific abnormalities of glycoprotein metabolism underlying these disorders are unknown at the present time.

Recently, human serum was found to contain several glycosyltransferases, namely, an $N$-acetylglucosaminyltransferase (30), an $N$-acetylgalactosaminyltransferase (21), a sialyltransferase (22) and a galactosyltransferase (31). It has also been found that in the case of the $N$-acetylgalactosaminyltransferase, which catalyzes the transfer of $N$-acetyl-D-galactosamine to human blood group H-like substances, and which is thus responsible for the human blood group A determinant, the enzyme was present in milk (32), intestinal tissue (13) and sera (21) of blood group A or AB individuals but was absent in individuals of group $B$ or $O$. However, no such variation in the enzyme activity among persons of different blood groups was noted in the case of the sialyltransferase (22) or the galactosyltransferase (31). Although present in the serum, the source and physiological significance of these enzymes remain unknown.

An examination of glycosyltransferases in the sera of several individuals revealed that one subject had an abnormally high galactosyltransferase level. It was found that this individual also had a liver disorder. Subse- 
quently this finding raised the question as to whether the elevated galactosyltransferase was the result of liver disease or merely an occurrence in many disease states. The present report describes the results obtained from an examination of the galactosyltransferase and the $N$-acetylgalactosaminyltransferase in 40 normal individuals and in 63 patients with various disorders. Levels of these enzymes were also determined in liver and intestine of two normal subjects at postmortem.

\section{METHODS}

Patient sera. Fresh sera were obtained from 40 healthy individuals, 18 patients with alcoholic liver diseases, 10 with miscellaneous liver diseases, 9 with viral hepatitis, 14 with cystic fibrosis of the pancreas, and 23 with miscellaneous diseases: carcinoma of the stomach, 3 , or colon, 5 , none of which showed evidence of hepatic metastasis; gastric ulcer, 5; pneumonia, 4; diabetes mellitus, 4 ; and sickle cell anemia, 2. Serum samples were stored at $-20^{\circ} \mathrm{C}$ until used.

Enzyme assays. For the galactosyltransferase assay, a quantitative assay method utilizing a fetuin acceptor free of $N$-acetylneuraminic acid and D-galactose was used and is fully described in a previous paper (31). For the $N$-acetylgalactosaminyltransferase, a standard assay method (20) was employed using porcine submaxillary mucin or 2 '-fucosyllactose as the acceptor. These acceptors both possessed human blood group $\mathrm{O}(\mathrm{H})$-like activity. All enzyme assays were performed under conditions in which the reaction was linear with respect to enzyme concentration and time. Control incubations were performed in the absence of either exogenous acceptor or enzyme, and the sum of amounts of radioactivity incorporated in both controls was subtracted from the total radioactivity in the calculation of enzyme activity. Unless stated otherwise, results are reported as totals of the radioactivity incorporated into the specific acceptor per hour of incubation per milligram of serum protein and per milliliter of serum.

Preparation of liver and small intestine postmitochondrial fraction. Postmortem liver and small intestinal tissues from two human blood group A secretors were obtained at $5 \mathrm{hr}$ (H. F.) and $24 \mathrm{hr}$ (M. R.) of death. All subsequent steps were done at $4^{\circ} \mathrm{C}$. Firstly, the intestinal tissue was scraped to obtain mucosa and the liver tissue was minced with a scissors. Next, the tissues were homogenized with 4 vol $(\mathrm{w} / \mathrm{v})$ of $0.05 \mathrm{M}$ Tris-acetate, $0.15 \mathrm{M}$ sodium chloride buffer $\mathrm{pH} 7.4$ using a Potter-Elvejhem tissue homogenizer with a Teflon pestle having a $0.004-0.006 \mathrm{~cm}$ clearance. Six and 12 strokes were used for the intestinal and liver tissues, respectively. The homogenates were centrifuged at $20,000 \mathrm{~g}$ for $10 \mathrm{~min}$, and the supernatant fluid was analyzed for glycosyltransferase activities using the serum assay conditions but including in addition $0.1 \%$ Triton X-100.

Protein content of samples was estimated by the method of Lowry, Rosenbrough, Farr, and Randall (33) using bovine serum albumin as a standard.

Cellulose acetate electrophoresis of human serum. $3 \mu \mathrm{l}$ of serum was applied to Sepraphore III cellulose acetate strips (Gelman Instrument Company, Ann Arbor, Mich.). Electrophoresis was performed at $4^{\circ} \mathrm{C}$ using a Gelman electrophoresis apparatus in the following systems: at $\mathrm{pH} 4.0,0.11 \mathrm{~m}$ sodium formate buffer, $200 \mathrm{v}$ (constant voltage), giving 1.5 ma per strip, for $45 \mathrm{~min}$; at $\mathrm{pH} \mathrm{9.0,} \mathrm{a} \mathrm{borate} \mathrm{buffer} \mathrm{contain-}$ ing $0.04 \mathrm{~m}$ sodium tetraborate and $0.02 \mathrm{M}$ boric acid, with $250 \mathrm{v}$ (constant voltage) and $1.5 \mathrm{ma}$ per strip, for $45 \mathrm{~min}$. After electrophoresis, the cellulose acetate strips were cut at 3-mm intervals along the strip length; each section was then
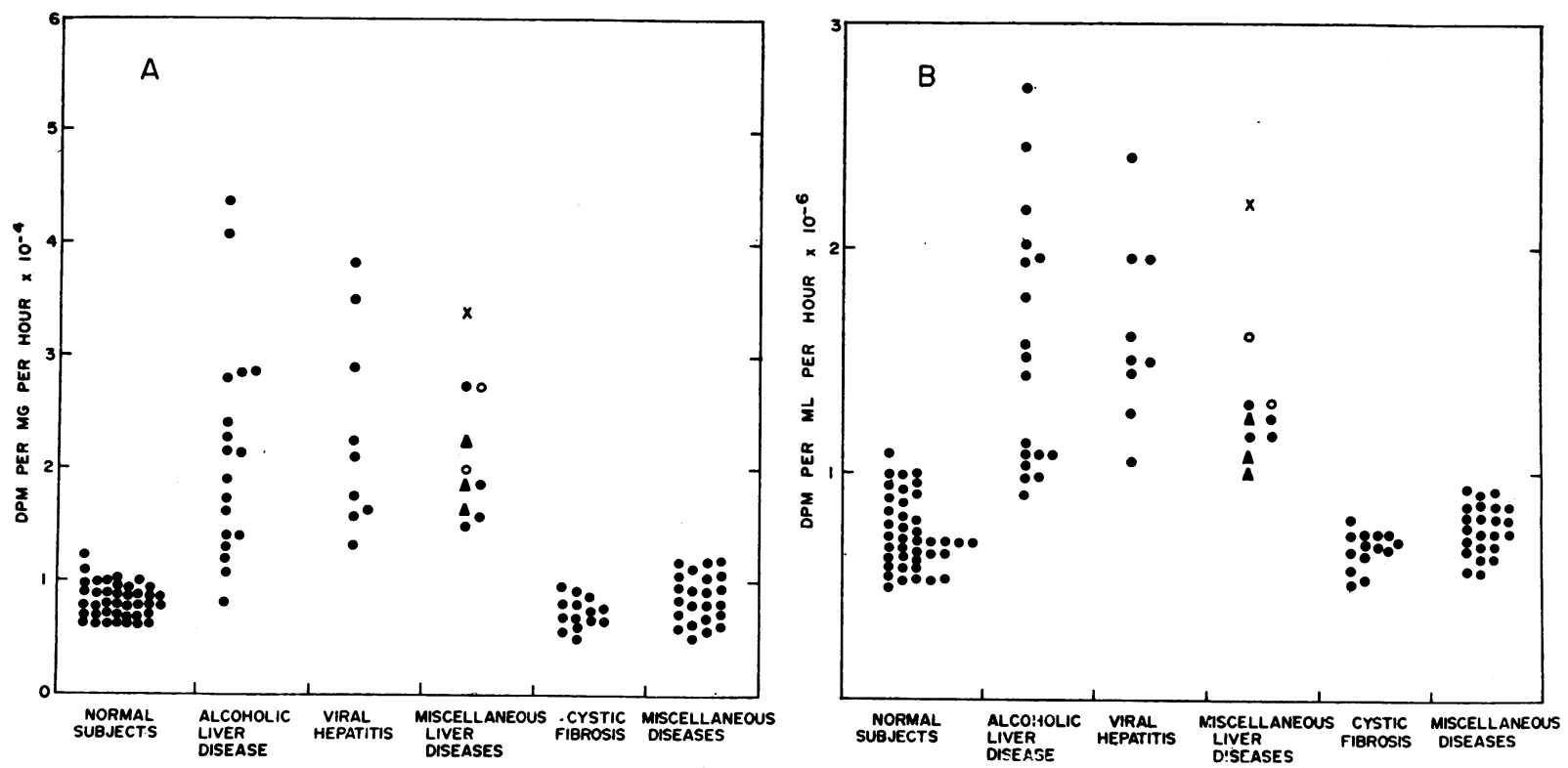

FIGURE 1 Level of galactosyltransferase activity in the serum of normal subjects and of patients with a variety of diseases. The miscellaneous liver disease symbols are: $\bullet$, liver metastasis with carcinoma of the stomach (1) or with carcinoma of the colon (3); $\boldsymbol{\Delta}$, hepatic congestion due to cardiac failure; $\times$, liver cell carcinoma. Miscellaneous diseases are listed in Methods. 
TABLE I

Serum Glycosyltransferase Activity in Normal Subjects and in Patients with Alcoholic Liver Disease

\begin{tabular}{|c|c|c|c|c|}
\hline \multirow[t]{2}{*}{ Serum source } & \multicolumn{2}{|c|}{$\begin{array}{l}\text { Galactosyltransferase } \\
\text { (fetuin acceptor) }\end{array}$} & \multicolumn{2}{|c|}{$\begin{array}{l}N \text {-acetylgalactosaminyltransferase } \\
\text { (PSM* acceptor) }\end{array}$} \\
\hline & $d p m / m g$ protein/hr $\ddagger$ & $d p m / m l / h r$ & $d p m / m g$ protein $/ h r$ & $d p m / m l / h r$ \\
\hline $\begin{array}{l}\text { Alcoholic liver disease } \\
\text { Normal }\end{array}$ & $\begin{array}{l}\text { (18) } 19,594 \pm 2,372 \\
(40) 8,359 \pm 226\end{array}$ & $\begin{array}{c}1,547,222 \pm 130,764 \\
704,870 \pm 2,448\end{array}$ & $\begin{array}{r}\text { (8) } 311 \pm 28 \\
\text { (18) } 294 \pm 14\end{array}$ & $\begin{array}{l}21,894 \pm 1,504 \\
22,439 \pm 1,165\end{array}$ \\
\hline
\end{tabular}

* PSM, porcine submaxillary mucin.

$\ddagger$ Mean \pm SE. Figures in parentheses indicate the number of subjects.

diced and added to the standard galactosyltransferase assay mixture. In these incubations $50,000 \mathrm{dpm}$ of UDP-galactose${ }^{14} \mathrm{C}(298 \mathrm{mCi} / \mathrm{mmole})$ was used as substrate and the incubation time was extended to $16 \mathrm{hr}$. Serum albumin mobility was determined by staining the control strips with $0.5 \%$ amido black in $7 \%$ acetic acid. The strips were destained with $7 \%$ acetic acid.

\section{RESULTS}

The level of the galactosyltransferase was measured in the sera of patients with a variety of disorders (Fig. 1). The sera from patients with alcoholic liver disease showed the highest elevations of enzyme activity although variation in the levels was also large. Similar levels and variations were found in viral hepatitis patients and in those with other liver diseases. In contrast, the serum galactosyltransferase activity was not elevated in patients with other disorders: cystic fibrosis, gastric ulcer, carcinoma of the stomach and colon with no evidence of hepatic metastasis, pneumonia, diabetes mellitus, and sickle cell anemia. The results were similar whether the enzyme activity was expressed per milligram of protein or per milliliter of serum. As shown in Table I, the activity of the serum $N$-acetylgalactosaminyltransferase was not elevated in patients with alcoholic liver disease as distinct from the rise in the galactosyltransferase observed in these patients.

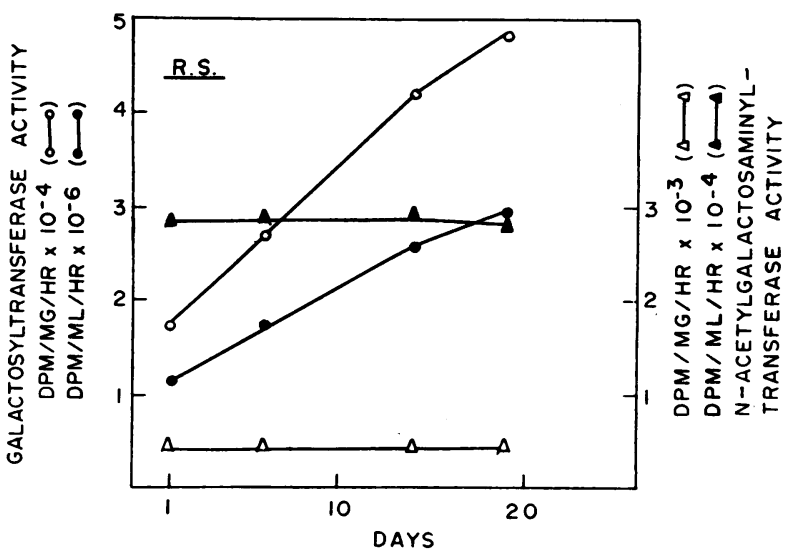

FIgURE 2 Serum glycosyltransferase levels measured at intervals in a patient (R. S.) with Laennec's cirrhosis.
Serum glycosyltransferase activities were measured at intervals in a patient (R. S.) with Laennec's cirrhosis, who died of hepatic failure (Fig. 2), and another (J.M.) who was recovering from acute alcoholic hepatitis (Fig. 3 ). In the cirrhosis patient (Fig. 2) the level of the galactosyltransferase activity increased markedly during the period of observation. The $N$-acetylgalactosaminyltransferase remained at the normal level. In the second case (Fig. 3), the recovery of liver function, as indicated by a decrease in serum bilirubin and in $\mathrm{SGOT}^{1}$ was accompanied by a drop in serum galactosyltransferase activity to the normal level.

In order to determine whether the presence of an activator or the absence of an inhibitor caused an apparent increase in the level of the serum galactosyltransferase in patients with liver disorders, various proportions of normal and liver disease sera were mixed and the enzyme activity measured (Table II). The galactosyltransferase activity of each mixture was equivalent to the sum of the individual activities of the two portions. The ratio of experimental to theoretical activity for each mixture was very close to 1 ; this was within the range of experimental error for the assay procedure.

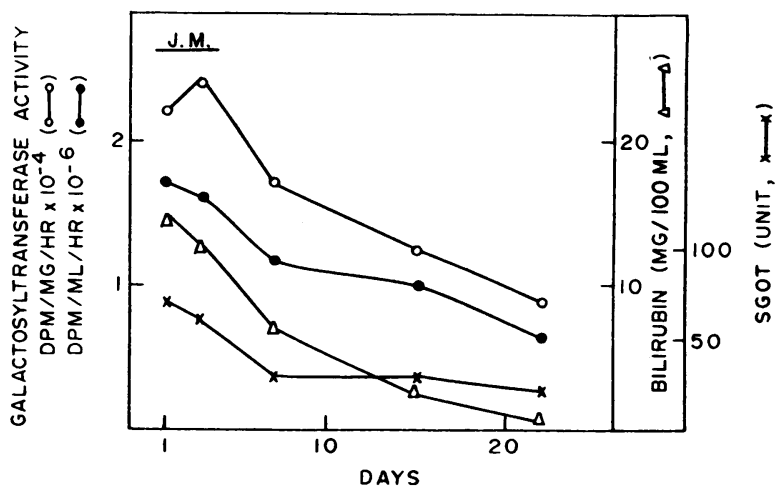

FIGURE 3 Galactosyltransferase level measured in a patient (J. M.) recovering from acute alcoholic hepatitis. SGOT, serum glutamic oxaloacetic transaminase.

${ }^{1}$ Abbreviations used in this paper: SGOT, serum glutamic oxaloacetic transaminase; UDP-galactose, uridine diphosphate galactose. 
TABLE II

Galactosyltransferase Activity in Mixtures of Serum from a Normal Subject and a Patient with Alcoholic Liver Disease

\begin{tabular}{|c|c|c|c|c|c|c|c|c|}
\hline \multirow[b]{3}{*}{ Mixture } & \multicolumn{2}{|c|}{ Serum portion } & \multirow{2}{*}{\multicolumn{6}{|c|}{ Enzyme activity }} \\
\hline & & & & & & & & \\
\hline & Normal & disease & Experimental & Theoretical* & Ratiof & Experimental & Theoretical* & Ratio \\
\hline & \multicolumn{2}{|c|}{$\mu l$} & \multicolumn{3}{|c|}{$\mathrm{dpm} / \mathrm{ml} / \mathrm{hr} \times 10^{-\mathrm{d}}$} & \multicolumn{3}{|c|}{$d p m / m g$ prolein $/ h r \times 10^{-2}$} \\
\hline 1 & 20 & 0 & 763 & - & - & 123 & 一 & 一 \\
\hline 2 & 15 & 5 & 1,269 & 1,295 & 0.98 & 214 & 202 & 1.06 \\
\hline 3 & 10 & 10 & 1,899 & 1,826 & 1.04 & 272 & 281 & 0.97 \\
\hline 4 & 5 & 15 & 2,476 & 2,358 & 1.05 & 363 & 360 & 1.01 \\
\hline 5 & 0 & 20 & 2,890 & - & - & 438 & 一 & - \\
\hline
\end{tabular}

* The theoretical values are those predicted from the sum of the individual activity of each portion.

$\ddagger$ Experimental/theoretical.

To examine the possible identity of the serum galactosyltransferase from liver disease patients and normal individuals, several properties of the enzyme were investigated (Table III). The enzyme activity of the serum from both sources was maximal at $\mathrm{pH} 7.0$ to 7.5 , $30^{\circ} \mathrm{C}$ and a manganous ion concentration of $43 \mathrm{~mm}$. The apparent $K_{m}$ for uridine diphosphate galactose (UDPgalactose) of the enzyme from both sources was also very similar.

Electrophoresis of the galactosyltransferase from the sera of normal and alcoholic liver disease individuals was performed for comparison on cellulose acetate strips at $\mathrm{pH} 4.0$ and $\mathrm{pH} 9.0$ as described in Methods. The results are shown in Fig. 4. At either $\mathrm{pH}$ value the enzyme from normal and liver disease subjects migrated the same distance from the origin and moved at a slower rate than serum albumin. Only a single peak of enzyme activity was ever observed.

The levels of both glycosyltransferases were measured in autopsy specimens of liver and intestine. The results are shown in Table IV. The galactosyltransferase was very active in both tissues. However, the $N$-acetylgalactosaminyltransferase activity, while high in the intestinal tissue, was at the limit of detection in the liver.

\section{TABLE III}

Comparison of the Properties of the Serum Galactosyltransferase in a Normal Subject and in an Alcoholic Liver Disease Patient

\begin{tabular}{lcccc}
\hline $\begin{array}{c}\text { Serum } \\
\text { source }\end{array}$ & $\begin{array}{c}\mathrm{pH}- \\
\text { optimum }\end{array}$ & $\begin{array}{c}\text { Mn++ } \\
\text { requirement }\end{array}$ & $\begin{array}{c}\text { Temperature } \\
\text { optimum }\end{array}$ & $\begin{array}{c}K_{m} \text { for } \\
\text { UDP-Gal }\end{array}$ \\
\hline & & $m M$ & ${ }^{\circ} \mathrm{C}$ & $M$ \\
$\begin{array}{l}\text { Normal } \\
\begin{array}{l}\text { Alcoholic liver } \\
\text { disease }\end{array}\end{array}$ & $7.0-7.5$ & 43 & 30 & $7.5 \times 10^{-6}$ \\
\hline
\end{tabular}

\section{DISCUSSION}

Two glycosyltransferases were examined in this report, a galactosyltransferase and an $N$-acetylgalactosaminyltransferase. The reactions catalyzed by these two enzymes are shown in Fig. 5. The galactosyltransferase was found to be present in the serum of all individuals (31); as reported previously (21) the $N$-acetylgalactosaminyltransferase is present only in individuals of blood group $A$ and $A B$ and is believed to be responsible for the formation of the blood group A determinant. Although these enzymes were also detected in the erythrocyte membrane $(21,31)$, the levels of the membrane enzymes were not measured in this study.

A significant elevation in serum galactosyltransferase activity occurred in patients with active liver diseases,

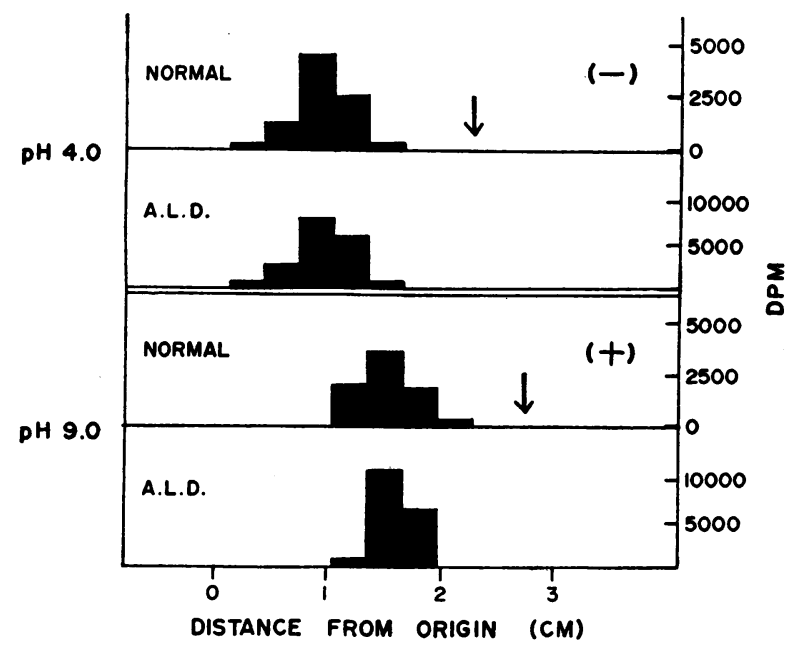

Figure 4 Cellulose acetate electrophoresis of the serum galactosyltransferase from a normal subject and an alcoholic liver disease patient (A. L. D.). " 0 " represents the point of application of the serum sample. The arrow represents the mobility of serum albumin. 
regardless of etiology. Alcoholic liver diseases, i.e., fatty liver or alcoholic hepatitis, viral hepatitis, cholestatic liver disease secondary to common duct stones and hepatic metastases from gastrointestinal cancer all resulted in the elevation of this enzyme. In addition, the activity of the galactosyltransferase rose with the levels of other indicators of liver dysfunction, e.g., serum bilirubin and SGOT. As depicted in Fig. 2, a patient with advanced Laennec's cirrhosis, who eventually died of hepatic decompensation, showed a progressive rise in the serum galactosyltransferase. This rise was concomitant with a clinical deterioration in liver function. Conversely, during recovery from acute alcoholic hepatitis (Fig. 3 ) the level of this enzyme returned to normal, coincident with the improvement in liver function as judged by a fall in serum bilirubin and SGOT. Patients with a variety of nonhepatic disorders showed no increase in the serum galactosyltransferase activity, suggesting that the elevation of this enzyme may occur only in patients with liver diseases, though the number of observations in patients with extrahepatic disease was not large.

The increase in serum galactosyltransferase activity observed in patients with active liver disease is apparently not due to the presence of an activator or the absence of an inhibitor in the serum, since mixtures of normal and pathological sera in different proportions yielded the expected additive enzyme activity. Electrophoresis of the serum at $\mathrm{pH} 4.0$ and 9.0 of a normal subject and of a patient with alcoholic liver disease showed a single band of galactosyltransferase activity. The electrophoretic mobility of the enzyme from normal and liver disease sera was the same. The identity of $\mathrm{pH}$, temperature, and $\mathrm{Mn}^{++}$ion concentration required for maximal activity and the similarity of the apparent $K_{m}$ for UDPgalactose in normal individuals and in patients with liver disease all suggest that the serum enzyme present in the liver disease patients is probably the same enzyme as that in the normal subjects.
TABLE IV

Glycosyltransferases in the Postmitochondrial Fraction of Human Liver and Intestine

\begin{tabular}{|c|c|c|c|c|}
\hline \multirow[b]{2}{*}{ Donor } & \multirow{2}{*}{$\begin{array}{l}\text { Speci- } \\
\text { men }\end{array}$} & \multirow{2}{*}{$\frac{\text { Galactosyltransferase }}{\text { Fetuin* }}$} & \multicolumn{2}{|c|}{$\begin{array}{c}N \text {-acetylgalactosaminyl- } \\
\text { transferase }\end{array}$} \\
\hline & & & PSM* & 2 fucosyllactose* \\
\hline & & $d p m / m g$ protein $/ h r$ & \multicolumn{2}{|c|}{$d p m / m g$ protein/hr } \\
\hline $\begin{array}{l}\text { M. R. } \\
\text { H. F. }\end{array}$ & Liver & $\begin{array}{r}9,200 \\
25,300\end{array}$ & $\begin{array}{r}80 \\
150\end{array}$ & $\begin{array}{l}90 \\
\text { ND }\end{array}$ \\
\hline $\begin{array}{l}\text { M. R. } \\
\text { H. F. }\end{array}$ & Intestine & $\begin{array}{l}21,300 \\
11,000\end{array}$ & $\begin{array}{l}30,100 \\
17,800\end{array}$ & $\begin{array}{l}15,900 \\
\mathrm{ND}\end{array}$ \\
\hline
\end{tabular}

ND, not determined.

* Acceptors used in assays. PSM, porcine submaxillary mucin.

Unlike the galactosyltransferase, the level of the $N$-acetylgalactosaminyltransferase did not rise in the serum of blood group $\mathrm{A}$ and $\mathrm{AB}$ patients with liver disease but remained the same as in the normal subjects. Presuming the liver is the source of the serum galactosyltransferase, as suggested by the rise in the enzyme during liver disorders, it would be surprising if the $N$-acetylgalactosaminyltransferase increased, since this organ showed a very low level of $N$-acetylgalactosaminyltransferase activity in normal patients.

It is possible that the elevation of the galactosyltransferase in the serum of patients with liver disorders is either due to detachment of the membrane enzymes from damaged cells or to a regeneration process in the liver. Roseman (34) has suggested that a galactosyltransferase plays an important role in the aggregation of embryonic retinal cells and Den, Kaufman, and Roseman (35) reported an activity of this enzyme in the serum and cerebral spinal fluid of the embryonic chick greater than that in the adult. However, the rise of the galactosyltransferase is probably not due to a regenerative process since patients with obstructive jaundice due to gallstones and hepatic congestion due to heart failure had an elevated level of this enzyme in serum. Since the enzyme is membrane-bound in liver $(11,12)$ and in other tissues (14,

(1) Galactosyltransferase :

UDP-Gal + GlcNAc-glycoprotein $\longrightarrow$ Gal-GlcNAc-glycoprotein + (UDP)

(2) $N$-acetylgalactosaminyltransferase:

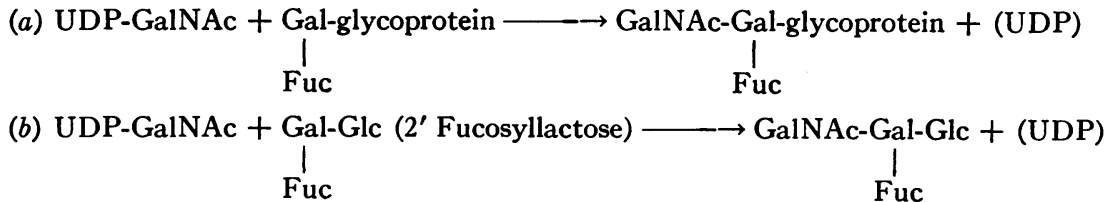

FIgURE 5 Summary of the reactions catalyzed by the galactosyltransferase and the $N$-acetylgalactosaminyltransferase. UDP-Gal, uridine diphosphate galactose; UDP-GalNAc, uridine diphosphate $N$-acetylgalactosamine; GlcNAc, $N$-acetylglucosamine; Gal, galactose; Fuc, fucose; Glc, glucose. 
$18,19,24)$ and since another liver membrane-bound enzyme, glucose-6-phosphatase, has also been shown to increase markedly in the serum of patients with acute hepatitis (36), the rapid fall of galactosyltransferase activity in serum during recovery suggests that the elevation of this enzyme is a result of hepatic cellular membrane damage.

Examination of a number of other serum glycosyltransferases in patients with various diseases may yield information helpful to the diagnosis of these disorders and may assist in elucidating the sources and physiological functions of the various glycosyltransferases.

\section{ACKNOWLEDGMENTS}

We gratefully acknowledge the excellent technical assistance of Miss Judith Nordberg and Mr. Yong Whan Kim, the secretarial aid of Mrs. Fay Avrech and the help of our librarian, Miss Eloise J. Ryan. We are indebted to Dr. Denis M. McCarthy for reviewing the manuscript.

This work was supported in part by Veterans Administration Research Grant and V. A. RE TR-48.

\section{REFERENCES}

1. Schmid, K. 1968. Isolation, characterization and polymorphism of glycoproteins. In Biochemistry of Glycoproteins and Related Substances. Proceedings of the Fourth International Conference on Cystic Fibrosis of the Pancreas. S. Karger. Basel. 244.

2. Jamieson, G. A. 1965. Studies on glycoproteins. II. Isolation of the carbohydrate chains of human transferrin. J. Biol. Chem. 240: 2914.

3. Clamp, J. R., and F. H. Putnam. 1964. The carbohydrate prosthetic group of human $\alpha$-globulin. J. Biol. Chem. 239: 3233.

4. Bahl, O. P. 1969. Human chorionic gonadotropin. II. Nature of the carbohydrate units. J. Biol. Chem. 244: 575.

5. Plummer, T. H., Jr., and C. H. W. Hirs. 1964. On the structure of bovine pancreatic ribonuclease $\mathrm{B}$ : isolation of a glycopeptide. J. Biol. Chem. 239: 2530.

6. Pigman, W., and G. Tettamanti. 1968. Chemistry of the mucins. In Biochemistry of Glycoproteins and Related Substances. Proceedings of the Fourth International Conference on Cystic Fibrosis of the Pancreas. S. Karger, Basel. 117.

7. Kim, Y. S., and M. I. Horowitz. 1971. Solubilization and chemical and immunochemical characterization of sparingly soluble canine gastric mucin. Biochim. Biophys. Acta. 236: 686.

8. Kabat, E. A. 1956. Blood Group Substances: Their Chemistry and Immunochemistry. Academic Press, Inc., New York.

9. Morgan, W. T. J. 1963. Some observations on carbohydrate containing components of human ovarian cyst mucin. Ann. N. Y. Acad. Sci. 106: 177.

10. Roseman, S. 1968. Biosynthesis of glycoproteins, gangliosides and related substances. In Biochemistry of Glycoproteins and Related Substances. Proceedings of the Fourth International Conference on Cystic Fibrosis of the Pancreas. S. Karger, Basel. 244.

11. Schachter, H., I. Jabbal, R. L. Hudgin, and L. Pinteric. 1970. Intracellular localization of liver sugar nucleotide glycoprotein glycosyltransferases in a Golgi-rich fraction. J. Biol. Chem. 245: 1090.

12. Fleischer, B., and S. Fleischer. 1970. Preparation and characterization of Golgi membranes from rat liver. Biochim. Biophys. Acta. 219: 301.

13. Hearn, V., Z. G. Smith, and W. Watkins. 1968. An $\alpha-N$-acetyl-D-galactosaminyltransferase associated with the human blood-group A character. Biochem. J. 109: 315 .

14. Kim, Y. S., J. Perdomo, and J. Nordberg. 1971. Glycoprotein biosynthesis in small intestinal mucosa. I. A study of glycosyltransferases in microsomal subfractions. J. Biol. Chem. 246: 5466.

15. Bella, Jr., A., and Y. S. Kim. 1971. Biosynthesis of intestinal glycoprotein: a study of an alpha $(1 \rightarrow 2)$ fucosyltransferase in rat small intestinal mucosa. Arch. Biochem. Biophys. 125: 1157.

16. Kim, Y. S., and J. Perdomo. Glycoprotein biosynthesis in small intestine. III. Enzymatic basis for the difference in the antigenicity of mucins. J. Clin. Invest. 51: 1135.

17. McGuire, E. J. 1968. Biosynthesis of submaxillary mucins. In Blood and Tissue Antigens. D. Aminoff, editor. Academic Press, Inc., New York. 461.

18. Schachter, H., E. J. McGuire, and S. Roseman. 1971. Sialic acids. XIII. A uridine diphosphate D-galactose: mucin galactosyltransferase from porcine submaxillary gland. J. Biol. Chem. 246: 5321.

19. Spiro, M. J., and R. G. Spiro. 1968. Glycoprotein biosynthesis: studies on thyroglobulin. Thyroid galactosyltransferase. J. Biol. Chem. 243: 6529.

20. Spiro, R. G. 1969. Glycoproteins: their biochemistry, biology and role in human disease (second part). N. Engl. J. Med. 281: 1043.

21. Kim, Y. S., J. Perdomo, A. Bella, Jr., and J. Nordberg. 1971. $N$-acetylgalactosaminyltransferase in human serum and erythrocyte membranes. Proc. Natl. Acad. Sci. U.S. A. 68: 1753 .

22. Kim, Y. S., J. Perdomo, A. Bella, Jr., and J. Nordberg. 1971. Properties of a CMP- $N$-acetylneuraminic acid: glycoprotein sialyltransferase in human serum and erythrocyte membranes. Biochim. Biophys. Acta. 244: 505.

23. Dische, Z., P. A. di Sant 'Agnese, Pallavicini, C., and J. Youlos. 1959. Composition of mucoprotein fractions from duodenal fluid of patients with cystic fibrosis and from controls. Pediatrics. 24: 74.

24. Chernick, W. S., G. J. Barbero, and F. M. Parkins. 1961. Studies on submaxillary saliva in cystic fibrosis. $J$. Pediatr. 59: 890.

25. Hoskins, L. C., and N. Zamcheck. 1965. Studies on gastric mucus in health and disease. II. Evidence for a correlation between $\mathrm{ABO}$ blood group specificity, $\mathrm{ABH}(\mathrm{O})$ secretor status, and the fucose content of the glycoproteins elaborated by the gastric mucosa. Gastroenterology. 48: 758 .

26. Hakkinen, I. P. T., and S. Virtanen. 1967. The blood group activity of human gastric sulphoglycoproteins in patients with gastric cancer and normal controls. Clin. Exp. Immunol. 2: 669 .

27. Alpert, M. E., J. Uriel, B. de Nechand. 1968. Alpha fetoglobulin in the diagnosis of human hepatoma. $N$. Engl. J. Med. 278: 984 .

28. Spiro, R. G., and M. J. Spiro. 1968. The carbohydrate of the glomerular basement: structure and enzymatic assembly. Diabetes. 17: 311 .

29. Gold, E. R., G. H. Tovey, W. E. Benney, and F. J. W. Lewis. 1959. Changes in the group A antigen in a case of leukaemia. Nature (Lond.). 183: 892. 
30. Mookerjea, S., A. Chow, and R. L. Hudgin. 1971. Occurrence of UDP- $N$-acetylglucosamine: glycoprotein $\mathrm{N}$-acetylglucosaminyltransferase activity in human and rat sera. Can. J. Biochem. 49: 297.

31. Kim, Y. S., J. Perdomo, and J. S. Whitehead. Glycosyltransferases in human blood. I. Galactosyltransferase in human serum and erythrocyte membranes. J. Clin. Invest. $51: 2024$.

32. Kobata, A., and V. Ginsburg. 1970. Uridine diphosphate$N$-acetyl-D-galactosamine: D-galactose $\alpha-3-N$-acetyl-D-galactosaminyltransferase, a product of the gene that determines blood type A in man. J. Biol. Chem. 245: 1484.
33. Lowry, O., N. Rosebrough, A. Farr, and R. J. Randall. 1951. Protein measurement with the Folin phenol reagent. J. Biol. Chem. 193: 265.

34. Roseman, S. 1970. The synthesis of complex carbohydrates by multiglycosyltransferase systems and their potential function in intracellular adhesion. Chem. Phys. Lipids. 5: 270.

35. Den, H., B. Kaufman, and S. Roseman. 1970. Properties of some glycosyltransferases in embryonic chicken brain. J. Biol. Chem. 245: 6607.

36. Secchi, G. C., A. Rezzonico, and N. Gervasini. 1967. Serum glucose-6-phosphatase activity in acute hepatitis. Enzymologia. 33: 134. 